\title{
Complex of Meningococcal Group B Polysaccharide and Type 2 Outer Membrane Protein Immunogenic in Man
}

\author{
W. D. Zollinger, R. E. Mandrell, J. M. Griffiss, P. Altieri, and \\ S. BERMAN, Department of Bacterial Diseases and Biologics Research, \\ Walter Reed Army Institute of Research, Washington, D. C. 20012
}

\begin{abstract}
A B S T RACT A noncovalent complex of meningococcal group $B$ polysaccharide and type 2 outer membrane protein has been characterized and its potential as a vaccine against group $B$ meningococcal disease investigated. The polysaccharide component was found to have a partition coefficient, $K_{d}$, of 0.34 on Sepharose CL-4B in the presence of sodium deoxycholate. The protein consisted of four to five major proteins including the principal outer membrane protein. Hydrophobic binding between the protein and polysaccharide was demonstrated by gel filtration and isopycnic $\mathrm{CsCl}$ density gradient centrifugation and found to involve all of the proteins. After demonstrating safety and immunogenicity in animals, two lots of vaccine were tested in a total of eight volunteers. Two $120-\mu$ g doses were given subcutaneously at 0 and $5 \mathrm{wk}$. Mild local reactions occurred in all eight volunteers, but no systemic reactions were observed. $2 \mathrm{wk}$ after the first dose, six of the volunteers had increased levels of bactericidal antibodies against both the group $B$ polysaccharide and the outer membrane proteins. Antibody rises to the group B polysaccharide (mean 6-fold) were confirmed by passive hemagglutination assays and rises to the proteins (mean 10-fold) by a solid phase radioimmunoassay. The second dose resulted in little or no increase in antibody titers. Antibody titers declined over a period of $14 \mathrm{wk}$ but mostly remained above preimmunization levels. Bactericidal antibodies with specificity for the group B polysaccharide were mostly of the immunoglobulin (Ig)M class, and were directed against a determinant associated only with high molecular weight polysaccharides. We conclude that both the group $B$ polysaccharide and the outer membrane protein are immunogenic in man when presented as a complex and that the complex warrants further testing and development as a vaccine against group B meningococcal disease.
\end{abstract}

Received for publication 11 September 1978 and in revised form 26 December 1978.

\section{INTRODUCTION}

Group B Neisseria meningitidis continues to be responsible for a major proportion of meningococcal disease in the United States (1), Europe (2), and England (3). Since the development of successful capsular polysaccharide vaccines for groups $A$ and $C$ in the late $1960 \mathrm{~s}$ (4), there has been a continuing effort in several laboratories to develop a suitable group B vaccine. Purified high molecular weight group $B$ polysaccharide has been reported to lack substantial immunogenicity in man (5). This result, together with evidence of poor antibody responses to the group $B$ polysaccharide after natural group B infection $(6,7)$, has led to the study of noncapsular surface antigens as potential vaccines $(8-11)$. The serotype 2 outer membrane protein has been of particular interest because in recent years serotype 2 strains have been responsible for a high percentage of group B disease $(3,12,13)$, and the outer membrane proteins can be separated from the toxic lipopolysaccharide (LPS) ${ }^{1}$ in a form that is both immunogenic and protective in animals $(8,11)$. Animal models, however, have thus far proven to be inadequate for predicting immunogenicity of meningococcal capsular polysaccharide (14) and outer membrane protein (8) antigens in human beings.

Because serum bactericidal activity has been correlated with immunity to meningococcal disease $(15,16)$, our approach has been to identify the group $B$ antigens against which human bactericidal antibodies are directed and to evaluate these antigens as potential vaccines. We have verified the presence of bactericidal antibodies specific for the serotype proteins in convalescent phase human sera; and, in contrast to the

${ }^{1}$ Abbreviations used in this paper: DOC, sodium deoxycholate; HA, hemagglutination; $K_{\mathrm{d}}$, partition coefficient; LPS, lipopolysaccharide; $\mathrm{MIC}_{50}$ minimum concentration resulting in $50 \%$ inhibition; OMC, outer membrane complex; SDSPAGE, sodium dodecyl sulfate polyacrylamide gel electrophoresis; SPRIA, solid phase radioimmunoassay; TS, Trisbuffered saline. 
findings of Wyle et al. (15) and Kasper et al. (17), we have found that most adult human sera contain bactericidal antibodies specific for the group B polysaccharide (8). ${ }^{2}$ The latter result suggested that group B-specific bactericidal antibodies might be induced by vaccination if the antigen were properly presented. In a previous study, an experimental serotype 2 outer membrane protein vaccine prepared from a group $\mathrm{C}$ strain produced a cross-stimulation of bactericidal antibodies to the group B polysaccharide in a small number of volunteers (8). These results suggested that outer membrane protein might function as an effective carrier for the group B capsular polysaccharide. Naturally occurring complexes of the capsular polysaccharide from Haemophilus influenzae and N. meningitidis with protein (presumably outer membrane protein) have been shown to exhibit increased immunogenicity in animals as compared with the purified polysaccharides $(17,18)$. In addition, induction of antibodies to both the group B polysaccharide and the serotype protein(s) may result in better protection than either specificity of antibody alone (19).

In the present report we show that both the group B polysaccharide and the type 2 outer membrane proteins are immunogenic in man when presented as a noncovalent complex.

\section{METHODS}

Bacterial strains. The group B $N$. meningitidis strains M1080(B:P11:L3,4,7,8), M981(B:P14:L5), M136(B:P4,7:L4), and M986(B:P2,6:L2,3,7) were provided by Dr. Carl Frasch, Bureau of Biologics, Food and Drug Administration, Bethesda, Md. All other strains were from the culture collection of Walter Reed Army Institute of Research, Washington, D. C. Serotype nomenclature is based on the solid phase radioimmunoassay (SPRIA) inhibition serotyping system (20) and is expressed by the format (serogroup:protein serotype:LPS serotype). (Serotype P2 is the same as type 2 in the system of Frasch and Chapman [21] and Factor II in the system of Gold and Wyle [22].) The group B strain 99M(B:P2,3,6:L3,7), which is also referred to as Bll, was used for production of the vaccines. The Escherichia coli strain $07: \mathrm{Kl}(\mathrm{L}): \mathrm{NM}$ was used for preparation of Kl capsular polysaccharide.

Preparation of vaccines. Cultures were grown in 15-liter bottles as described (23) for $16 \mathrm{~h}$ at $36^{\circ} \mathrm{C}$ in the medium of Watson and Sherp (24) modified to contain $3 \%$ casamino acids (Certified, Difco Laboratories, Detroit, Mich.) and $0.1 \%$ glucose. Final pH after growth was 7.7-8.0.

Lot BP2-WZ-2 was prepared by combining partially purified group B polysaccharide from one culture with outer membrane complex (OMC) prepared from a second culture grown under the same conditions. The mixture was then processed further to remove LPS.

The partially purified group B polysaccharide was prepared by a modification of the method of Gotschlich et al. (14). After addition of $0.1 \%$ hexadecyltrimethylammonium bromide to the culture, the precipitate was collected by continuous flow

${ }^{2}$ Zollinger, W. D., and R. E. Mandrell. 1977. Abstracts of the Annual Meeting of the American Society for Microbiology, New Orleans, La. E116. 100. centrifugation and extracted three times with $1 \mathrm{M} \mathrm{CaCl}_{2}$. After centrifugation at $30,000 \mathrm{~g}$ for $30 \mathrm{~min}$ at $4^{\circ} \mathrm{C}$, the supernates were pooled and cold ethanol added to a concentration of $25 \% \mathrm{vol} / \mathrm{vol}$. After standing overnight at $5^{\circ} \mathrm{C}$, the precipitated nucleic acid was removed by centrifugation at $16,000 \mathrm{~g}$ for $10 \mathrm{~min}$. Cold ethanol was added to the supernate to a final concentration of $67 \%$, and the precipitated polysaccharide collected after $30 \mathrm{~min}$ by centrifugation at $16,000 \mathrm{~g}$ for 10 min. The precipitate was washed twice with cold absolute ethanol and dissolved in cold distilled water. The solution was dialyzed overnight at $5^{\circ} \mathrm{C}$ against $10 \mathrm{vol}$ distilled water and reprecipitated by addition of $1 / 10 \mathrm{vol}$ of saturated sodium acetate followed by $2 \mathrm{vol}$ of cold ethanol. The precipitate was collected by centrifugation at $16,000 \mathrm{~g}$ for $10 \mathrm{~min}$ and dissolved in distilled water. The sialic acid:protein ratio of this product was 1.6:1.

The OMC was prepared from 15 liters of culture after inactivation by $0.5 \%$ phenol for $2 \mathrm{~h}$. The organisms ( $135 \mathrm{~g}$ wet wt) were collected by continuous flow centrifugation, suspended in $300 \mathrm{ml}$ buffer containing $0.05 \mathrm{M}$ Tris-chloride, 0.15

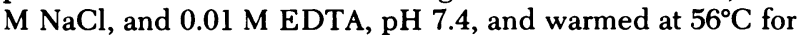
$30 \mathrm{~min}$. The suspension was then allowed to cool to room temperature, sheared in an Omnimixer (Dupont InstrumentsSorvall, DuPont Co., Newtown, Conn.) at full speed for $3 \mathrm{~min}$, and centrifuged at $16,000 \mathrm{~g}$ for $15 \mathrm{~min}$. The pellets were reextracted in the same way, and the supernates combined. The combined supernate was centrifuged first at $25,000 \mathrm{~g}$ for 15 $\mathrm{min}$ and then at $30,000 \mathrm{~g}$ for $20 \mathrm{~min}$. The resulting supernate was centrifuged at $100,000 \mathrm{~g}$ for $2 \mathrm{~h}$ and the pelleted OMC suspended in about $300 \mathrm{ml}$ of distilled water. The OMC was washed once by repelleting at $100,000 \mathrm{~g}$ for $2 \mathrm{~h}$ and suspended in $150 \mathrm{ml}$ of distilled water. Enough of this suspension was combined with the partially purified capsular polysaccharide to make the sialic acid:protein ratio $1: 1.2$, and the resulting mixture was stored at $-20^{\circ} \mathrm{C}$ in $60-\mathrm{ml}$ portions.

LPS was removed by chromatography of each portion on Sephadex G-100 (Pharmacia Fine Chemicals, Piscataway, N. J.) in buffer containing $1 \%$ sodium deoxylcholate (DOC), $0.05 \mathrm{M}$ glycine, and 0.005 M EDTA, pH 8.8. Each 60-ml sample was mixed with $30 \mathrm{ml}$ of buffer concentrate containing $10 \%$ DOC, $0.15 \mathrm{M}$ glycine, and $0.03 \mathrm{M}$ EDTA, pH 8.8. The mixture was then warmed at $56^{\circ} \mathrm{C}$ for $30 \mathrm{~min}$ and centrifuged at $25,000 \mathrm{~g}$ for $10 \mathrm{~min}$ at $20^{\circ} \mathrm{C}$. The pellets were discarded, and the supernate applied to the $5 \times 90-\mathrm{cm}$ column. The fractions $(20 \mathrm{ml})$ comprising the void volume peak that contained the protein and sialic acid were pooled and kept at $5^{\circ} \mathrm{C}$ until all five samples had been chromatographed $(4 \mathrm{~d})$. The pooled fractions were warmed to $30^{\circ} \mathrm{C}$ and prefiltered through a $0.45-\mu \mathrm{m}$ membrane filter. The prefiltered material was then sterile filtered through a $0.2-\mu \mathrm{m}$ membrane filter directly into 4 vol of cold, filter-sterilized ethanol. The resulting precipitate was collected by centrifugation at $16,000 \mathrm{~g}$ for $10 \mathrm{~min}$ at $4^{\circ} \mathrm{C}$, washed three times with sterile absolute ethanol, and dissolved in sterile distilled water. The bulk product, which was soluble but slightly opalescent, was stored at $-60^{\circ} \mathrm{C}$.

Lot BP2-PA-3 was prepared from 30 liters of culture essentially as described for the partially purified capsular polysaccharide component of lot BP2-WZ-2. Differences in the procedure were that $(a)$ the precipitate obtained by addition of hexadecyltrimethylammonium bromide was washed twice with water before extraction with $1 \mathrm{M} \mathrm{CaCl}_{2}$, and that $(b)$ the reprecipitated polysaccharide-protein complex was washed four times with ethanol, dissolved in distilled water, and lyophilized. The lyophilized material was dissolved in distilled water at $1 \mathrm{mg} / \mathrm{ml}$ and prefiltered through $1.2-\mu \mathrm{m}$ and then $0.45-\mu \mathrm{m}$ membrane filters. Sterile filtration was accomplished 
by passage through two sterile $0.45-\mu \mathrm{m}$ membrane filters. The bulk filtrate was stored at $-60^{\circ} \mathrm{C}$.

Physical and chemical characterization of the vaccines. Before chemical analysis, samples were dried to constant weight under vacuum over $\mathrm{P}_{2} \mathrm{O}_{5}$ at $60^{\circ} \mathrm{C}$. Assays for protein, 2-keto-3-deoxyoctonate, sialic acid, and nucleic acid were performed as described (6).

The molecular size of the vaccines was determined by chromatography on a $2.5 \times 37-\mathrm{cm}$ column of Sepharose CL-4B (Pharmacia Fine Chemicals) equilibrated with either $0.05 \mathrm{M}$ Tris-Cl, $0.15 \mathrm{M} \mathrm{NaCl}, \mathrm{pH} 7.4$, Tris-buffered saline (TS), or $1 \% \mathrm{DOC}, 0.05 \mathrm{M}$ glycine, $0.005 \mathrm{M}$ EDTA, $\mathrm{pH}$ 8.8. In the latter instance, the sample was first equilibrated in $3 \%$ DOC, $0.01 \mathrm{M}$ EDTA, and $0.05 \mathrm{M}$ glycine, $\mathrm{pH}$ 8.8. Determination of the partition coefficient, $K_{d}$, was done as described by Wong et al. (25).

$\mathrm{CsCl}$ equilibrium density gradient analysis of the vaccines was performed with an initial one-step gradient (26) with a density of $1.8 \mathrm{~g} / \mathrm{cm}^{3}$ in the lower half and $1.3 \mathrm{~g} / \mathrm{cm}^{3}$ in the upper half. Tris-Cl buffer was present at a concentration of $0.01 \mathrm{M}$ and $\mathrm{pH} 7.8$ throughout, and the vaccine was initially uniformly distributed in the upper solution. Centrifugation was performed in a Beckman $50 \mathrm{Ti}$ angle head rotor (Beckman Instruments, Spinco Div., Palo Alto, Calif.) at 42,000 rpm and $10^{\circ} \mathrm{C}$ for $73 \mathrm{~h}$. Fractions were collected, and the refractive index, sialic acid concentration, and optical density at $280 \mathrm{~nm}$ determined for each. Before analysis on polyacrylamide gels, pooled fractions were dialyzed against distilled water and lyophilized.

Sodium dodecyl sulfate polyacrylamide gel electrophoresis (SDS-PAGE) was performed on $8 \times 14 \times 0.25-\mathrm{cm}$ polyacrylamide slabs by a modification of the method of Laemmli (27). The concentration of acrylamide was $12.5 \% \mathrm{wt} / \mathrm{vol}$ in the resolving gel and $3.6 \%$ in the stacking gel. $N, N^{\prime}$-diallyltartardiamide was used as the cross-linker at concentrations of 0.54 and $0.156 \% \mathrm{wt} / \mathrm{vol}$, respectively. The electrode buffer concentration was doubled, and both the stacking and resolving gels contained $0.5 \mathrm{M}$ urea. Fixing and staining of the gel slabs was performed as described by Weber and Osborne (28). Densitometer tracings of stained slabs were made with a Zeineh Soft Laser Scanning Densitometer (Biomed Instruments, Inc., Chicago, Ill.).

Serological assays. Radioactive bactericidal assays were done by the method of Kasper and Wyle (29) with serum from 1-mo-old rabbits as a source of complement. The end point was taken as the highest dilution giving $50 \%$ of the maximum net release of radioactivity. Freezing and thawing of sera were kept to a minimum, and prevaccination sera, together with one or more postvaccination sera from all volunteers, were tested against a given strain in the same assay. Based on replicate assays of a single serum, estimated 95\% confidence levels for titers obtained in a single assay were plus or minus $14 \%$ of the number of serial two-fold dilutions.

For bactericidal inhibitions, a constant dilution of antiserum was preincubated for $1 \mathrm{~h}$ at $36^{\circ} \mathrm{C}$ with serial dilutions of antigen. The highest dilution of antibody that could produce maximum release of radioactivity was used in each case and the amount of antigen required to produce $50 \%$ inhibition was determined from a plot of percentage of ${ }^{14} \mathrm{C}$ release vs. $\log$ (inhibitor concentration).

Absorption of antisera with bacterial cells was performed as described (20), and absorption with alum-adsorbed LPS or capsular polysaccharide was done as described by Goldschneider et al. (30).

The SPRIA was performed as described (31). Calculation of micrograms antibody protein per milliliter was performed by reference to a calibrated serum having a known amount of specific antibody per milliliter as determined by quantitative precipitin assays. Calibration of the assay for determination of IgG, IgA, and IgM antibodies was done by reference to standard curves constructed by allowing serial dilutions of samples containing known amounts of IgA, IgG, or IgM to be bound by the corresponding heavy chain-specific goat antihuman immunoglobulin adsorbed to the surface of a plate. The assay was then completed as described (31) with the homologous heavy chain-specific ${ }^{125}$ I-goat anti-human immunoglobulin to detect the amount of human antibody bound. SPRIA inhibition assays were performed as described (20) by using an antigen concentration of $100 \mu \mathrm{g}$ protein $/ \mathrm{ml}$ except that in cases where a minimum concentration resulting in $50 \%$ inhibition $\left(\mathrm{MIC}_{50}\right)$ is given, serial twofold dilutions of the antigen were tested and the concentration required to give $50 \%$ inhibition was determined. The OMC, LPS antigens, and purified meningococcal and $E$. coli $\mathrm{Kl}$ capsular polysaccharides were prepared as described $(6,8)$.

The percentage of anti-99M antibodies as detected by SPRIA that were specific for the type 2 protein was estimated by inhibition with OMC from strains of several different serotypes. The percentage of inhibition by an excess of OMC (100 $\mu \mathrm{g}$ protein $/ \mathrm{ml}$ ) from the homologous strain, three type P2 strains [M1011(B:P2,6,10:L3,7), M986(B:P2,6:L2,3,7) and 138I(C:P2:L3)], and three nontype P2 strains [32I(C:P6:L2,4), M981(B:P14:L5), and M1080(B:P11:L3,4,7,8)] was determined. The percentage of antibody specific for the type 2 protein was then estimated by the expression: (Mean type P2 inhibition - mean nontype P2 inhibition) / (homologous inhibition) $\times 100$. Passive hemagglutination (HA) assays were done as previously described with formalin-fixed human type $\mathrm{O}$ negative erythrocytes (32). Fractionation of serum to separate IgM, IgG, IgA antibody classes was performed as described by Griffiss et al. (33).

Safety and immunogenicity in animals. The degree of immunogenicity of the vaccines in rabbits was determined by giving two $120-\mu$ g (dry weight) doses either subcutaneously or intravenously $3 \mathrm{wk}$ apart. Sera were obtained at 0,1 , and 4 wk.

Toxicity tests in mice and general safety tests in mice and guinea pigs were performed as described in sections 620.5 and 610.11, respectively, of the Code of Federal Regulations. ${ }^{3}$ Pyrogenicity of the vaccines in rabbits was investigated by testing serial dilutions to determine the largest nonpyrogenic dose. Tests were performed as described in section 610.13 (b) of the Code of Federal Regulations. ${ }^{3}$

Immunization of volunteers. 20 laboratory volunteers were prescreened for nasopharyngeal carriage of $N$. meningitidis and for antibody to the protein and polysaccharide components of the vaccine. Eight of the noncarriers with the lowest titers of bactericidal antibody were chosen to receive the vaccines and provided signed consent according to U.S. Army regulations. The volunteers consisted of seven males and one female and ranged in age from 25 to $54 \mathrm{yr}$. Four volunteers were vaccinated with lot BP2-WZ-2 and four with lot BP2-PA-3. Two doses of $120 \mu \mathrm{g}$ (dry weight) each were given subcutaneously in the deltoid region 5 wk apart. 30 min before each injection, a skin test was performed by giving $1 \mu \mathrm{g}$ of vaccine in $0.1 \mathrm{ml}$ of $0.9 \%$ sodium chloride intradermally in the volar region of the forearm. As a control, $0.1 \mathrm{ml}$ of $0.9 \%$ sodium chloride solution was given in the other arm. Throat cultures, serum samples, and stool samples were obtained at $0,2,5,7,10$, and 14 wk. Throat cultures

\footnotetext{
${ }^{3}$ Code of Federal Regulations, Title 21, Food and Drugs. 1974. Department of Health, Education and Welfare, Food and Drug Administration, Washington, D. C.
} 
were performed and evaluated as described by Artenstein et al. (34). Serum samples were divided into aliquots and stored at $-20^{\circ} \mathrm{C}$. Rectal swabs were placed in trypticase soy broth and streaked onto group B halo plates within $2 \mathrm{~h}$. The halo plates, which contained $10 \%$ hyperimmune horse serum to group B $N$. meningitidis, were used to screen for the presence of cross-reactive enteric organisms (35). Hyperimmune horse serum was kindly supplied by Dr. J. B. Robbins, Bureau of Biologics, Bethesda, Md. Local reactions at the sites of the skin test and the vaccination were observed and evaluated for the extent of erythema, induration, and tenderness at $4,24,48$, and $72 \mathrm{~h}$. Volunteers were questioned regarding the occurrence of any systemic reactions at 4 and $24 \mathrm{~h}$.

\section{RESULTS}

Composition. Vaccine lots BP2-WZ-2 and BP2PA-3 both consisted principally of group B capsular polysaccharide complexed to outer membrane proteins from the group B type P2,3,6 strain 99M (Table I). Protein plus silaic acid accounted for about $95 \%$ of the dry weight of lot BP2-WZ-2 and 87\% of lot BP2-PA-3. Nucleic acid was $\cong 1 \%$, and although trace amounts of LPS were present, 2-keto-3-deoxyoctonate could not be directly determined by colorimetric assay due to strong interference by sialic acid. Rabbit pyrogen tests indicated that the level of LPS in lot BP2-PA-3 was severalfold higher than in BP2-WZ-2 (see below).

The vaccines were analyzed by SDS-PAGE to determine the number of polypeptides present and the relative amount and molecular weight of each. Densitometer tracings of the stained slab are shown in Fig. 1. The two vaccine lots exhibited the same five major bands, which are also typical of the OMC from strain $99 \mathrm{M}$, but differed in the relative proportions of each. Band 1 is a high molecular weight protein with an estimated molecular weight of $>150,000$ daltons. Band 3 , with a molecular weight of about 43,000 daltons, is the "principal" outer membrane protein and corresponds to the 41,000 -dalton protein that has been reported to carry the protein serotype 2 determinants (36). The discrepancy in molecular weight is likely a reflection of the different gel systems used. This band

TABLE I

Chemical Composition

\begin{tabular}{lcc}
\hline & \multicolumn{2}{c}{ Vaccine lot } \\
\cline { 2 - 3 } Component & BP2-WZ-2 & BP2-PA-3 \\
\hline Protein & $445 \pm 20^{*}$ & $323 \pm 10$ \\
Sialic acid & $509 \pm 13$ & $543 \pm 19$ \\
Nucleic acid & 5 & 12 \\
Total & 959 & 878
\end{tabular}

Values for nucleic acid content are based on a single determination.

* Mean \pm SD of four determinations expressed as micrograms per milligram dry weight.

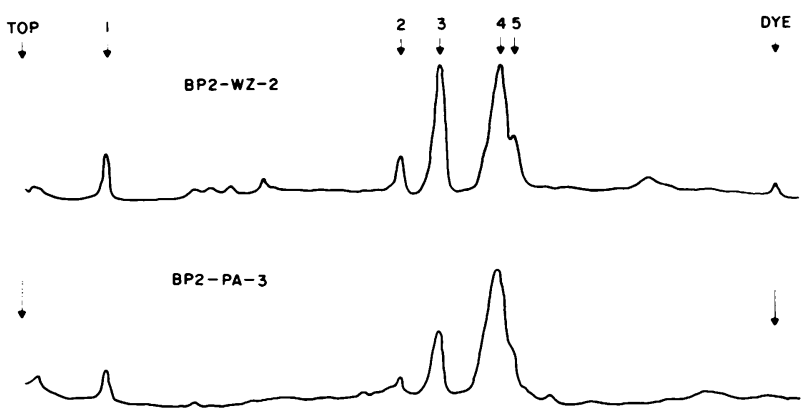

FIGURE 1 Densitometer tracings of meningococcal group B vaccine lots BP2-WZ-2 and BP2-PA-3 resolved by SDS-PAGE. The gel slab was stained with Coomassie Brilliant Blue R250.

represents $26 \%$ of the protein in lot BP2-WZ-2 and $14 \%$ of the protein in lot BP2-PA-3. Bands 4 and 5, which are actually three to four poorly resolved bands, comprise about half of the total protein in these lots.

Physical properties. The extent and nature of the interaction between the protein and polysaccharide components of the vaccine were investigated in two ways. Gel filtration of the vaccines on Sepharose CL-4B in the presence or absence of $1 \%$ DOC suggested there was considerable binding between the two components. In the absence of DOC (Fig. 2A), most of the polysaccharide and protein coeluted at the void volume followed by a second smaller peak at a $K_{\mathrm{d}}$ of about 0.35 . In the presence of DOC, however, the polysaccharide appeared smaller in size, eluting as a single peak with a $K_{d}$ of 0.34 , and the protein eluted in several peaks independently of the polysaccharide (Fig. 2B). More convincing evidence of protein-polysaccharide binding was obtained by isopycnic density gradient centrifugation of the vaccines in $\mathrm{CsCl}$. The profile obtained with lot BP2-WZ-2 is shown in Fig. 3A and compared with purified group B polysaccharide containing only about $1 \%$ protein in Fig. 3B. The B polysaccharide alone produced a single band at a density of $1.66 \mathrm{~g} / \mathrm{cm}^{3}$, whereas the B polysaccharide in the vaccine was found at all densities between 1.66 $\mathrm{g} / \mathrm{cm}^{3}$ and the top of the gradient $\left(1.47 \mathrm{~g} / \mathrm{cm}^{3}\right)$. Similarly, the protein in the vaccine was found not only at the top of the gradient, where pure protein would be expected to band, but at all densities down through the gradient to the point where the pure polysaccharide banded. The ultraviolet absorbance at the bottom of the gradients was probably the result of contaminating nucleic acid. These results demonstrated binding of the protein to the polysaccharide in widely variable proportions. To determine whether any particular protein was binding to the polysaccharide preferentially, the fractions were divided into three pools as indicated in Fig. 3A, and the material in each pool subjected to SDS-PAGE (Fig. 4). Exactly the same proteins were found in all three pools, although only very little protein was present in pool 1 . 

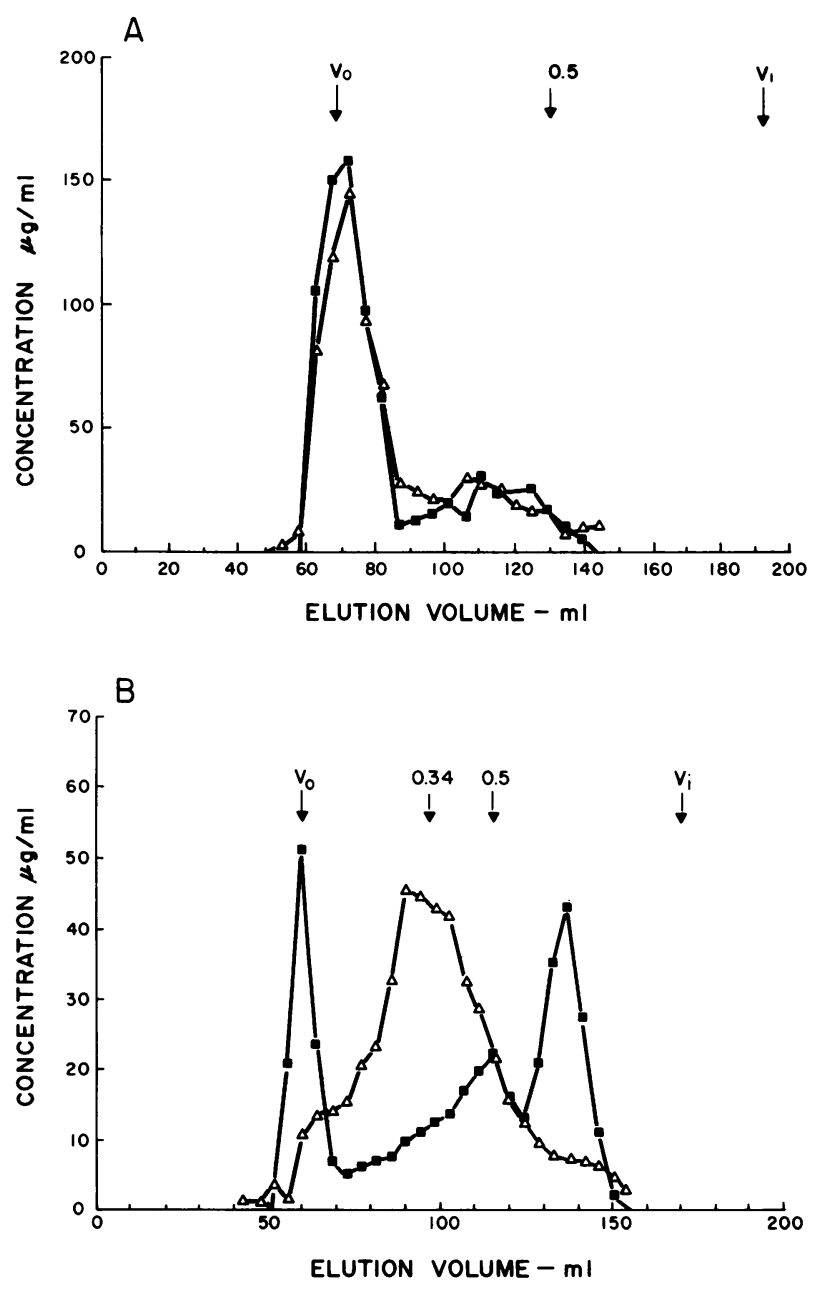

FIGURE 2 Elution profile of meningococcal group B vaccine lot BP2-WZ-2 on Sepharose CL-4B in the absence (A) or presence (B) of $1 \%$ DOC. Fractions were assayed for sialic acid $(\Delta)$ and for protein $(\square)$. Arrows indicate the void volume (Vo), the total volume of liquid in the column $(\mathrm{Vi})$, and points corresponding to the indicated $K_{d}$ values.

These results indicate that all the proteins participated in the binding either individually or as an aggregate. Because detergent but not high salt dissociates the binding, it is probably hydrophobic in nature.

Because of the protein-polysaccharide binding, the size of the polysaccharide component had to be determined in the presence of detergent. Thus, in Table II the size of the polysaccharide component is expressed in terms of the $K_{d}$ of the polysaccharide peak on Sepharose CL-4B in 1\% DOC and the percentage eluting before a $K_{d}$ of 0.15 and 0.5 . The percentages eluting before a $K_{\mathrm{d}}$ of 0.15 and 0.5 in TS buffer are also given for reference. The percentage of the polysaccharide that elutes in the void volume peak (before a $K_{d}$ of 0.15 ) in TS buffer was used as an estimate of the extent of the protein-polysaccharide binding be- cause very little polysaccharide elutes at the void in the presence of DOC. Thus, the polysaccharide components of the two vaccine lots appeared identical in size, but a higher percentage of the polysaccharide in lot BP2-WZ-2 was bound to protein (72 vs. $61 \%)$. This is likely a reflection of the higher proportion of protein in this lot.

Antigenic activity. Both the polysaccharide and the protein components of the vaccine were tested in several in vitro assays for antigenic activity. The capacity of the polysaccharide component of the vaccines to inhibit human group B-specific bactericidal antibodies was compared with several other group B polysaccharide preparations and with $E$. coli $\mathrm{Kl}$ capsular polysaccharide, which has the same antigenic specificity as the meningococcal group B polysaccharide (37) (Table III). The $\mathrm{MIC}_{50}$ of vaccine lots BP2-WZ-2 and BP2-PA-3 was about $10 \mu \mathrm{g} / \mathrm{ml}$. This was about twofold lower than the most active of the purified group $B$ polysaccharide preparations (lot 3XCA) previously tested in human beings by Wyle et al. (5) and fivefold lower than a preparation of $E$. coli $\mathrm{K} 1$ capsular polysac-
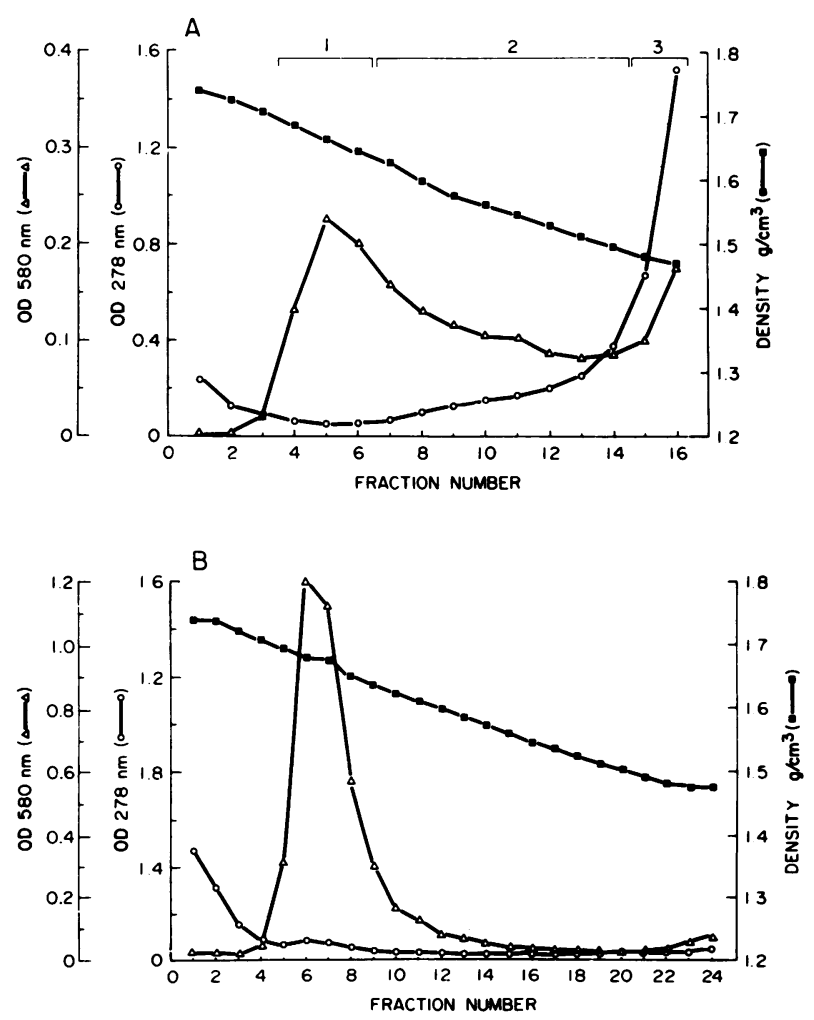

FIGURE 3 Isopycnic $\mathrm{CsCl}$ density gradient centrifugation of meningococcal group B vaccine lot BP2-WZ-2 (A) and purified group B polysaccharide (B). Fractions were assayed for protein by ultraviolet absorbance at $278 \mathrm{~nm}(O)$ and for sialic acid by the resorcinol assay $(\Delta)$. Fractions indicated by the numbered brackets were pooled and analyzed by SDS-PAGE (see Fig. 4). 


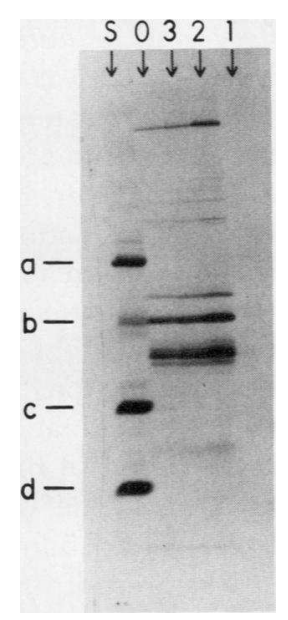

FIGURE 4 SDS-PAGE of pooled fractions from $\mathrm{CsCl}$ density gradient of meningococcal group B vaccine lot BP2-WZ-2 (see Fig. 3). Molecular weight standards: bovine serum albumin $(a)$, ovalbumin $(b)$, chymotrypsinogen $A(c)$, and ribonuclease $(d)$ were placed in the well labeled $S$. The vaccine before fractionation $(O)$ and pools 1,2 , and 3 from the gradient were placed in the other wells as indicated.

charide. Group B polysaccharide partially degraded $\left(K_{\mathrm{d}}=0.63\right)$ by mild acid hydrolysis $\left(\mathrm{pH} 5,40^{\circ} \mathrm{C}, 2 \mathrm{~h}\right)$ lacked detectable inhibitory activity. This agrees with an earlier report of loss of the capacity to inhibit a group $\mathrm{B}$ passive $\mathrm{HA}$ reaction after exposure to $\mathrm{pH} 5$ (38). An initial lot of protein-polysaccharide vaccine (lot BP2-WZ-1), which became degraded during the course of its preparation $\left(K_{\mathrm{d}}=0.59\right)$ had about eightfold less activity than lots BP2-WZ-2 and BP2-PA-3 $\left(K_{\mathrm{d}}=0.34\right)$. It is also noteworthy that in lot BP2-WZ-1 only $10 \%$ of the polysaccharide was bound to protein.

The antigenic activity and specificity of the protein antigens in the vaccines were investigated by measuring their capcity to inhibit serotype-specific antibodies in both bactericidal and SPRIA test systems (Table IV). In both systems $<10 \%$ inhibition was obtained with 99M LPS, group B polysaccharide, or OMC from the nontype P2 strains 32I(C:P6), M981(B:P14), and $\mathrm{M} 1080$ (B:P11) at $100 \mu \mathrm{g}$ protein $/ \mathrm{ml}$. On the other hand, OMC from the three serotype P2 strains, 138I(C:P2), M1011(B:P2,6,10), or M986(B:P2,6), gave at least $80 \%$ inhibition at $100 \mu \mathrm{g} / \mathrm{ml}$ in the SPRIA test system; and OMC from strains 138I(C:P2) and M986(B:P2,6), but not M1011 (B:P2,6,10), gave $>80 \%$ inhibition in the bactericidal test system. Thus, the SPRIA test system appeared to be serotype $\mathrm{P} 2$ specific and the bactericidal test system was specific for a protein present on some but not all serotype P2 strains (serotype 2 associated). Clear differences in the capacity of these test systems to distinguish among the antigens tested are evident. The protein determinant against which the human, naturally acquired bacterici-
TABLE II

Sizing of the Polysaccharide Component of the Vaccines on Sepharose CL-4B*

\begin{tabular}{|c|c|c|c|c|c|}
\hline \multirow[b]{2}{*}{ Vaccine lot } & \multirow{2}{*}{$\begin{array}{c}\boldsymbol{K}_{\mathrm{d}} \\
\text { DOC }\end{array}$} & \multicolumn{2}{|c|}{$\begin{array}{c}\text { Percentage } \\
\text { of eluting, } \\
\text { before } K_{\mathrm{d}} \\
\text { of } 0.5\end{array}$} & \multicolumn{2}{|c|}{$\begin{array}{c}\text { Percentage } \\
\text { of eluting } \\
\text { before } K_{\mathrm{d}} \\
\text { of } 0.15\end{array}$} \\
\hline & & DOC & TS & DOC & TS \\
\hline BP2-WZ-2 & 0.34 & 81 & 85 & 16.6 & 72 \\
\hline BP2-PA-3 & 0.34 & 82 & 94 & 11.4 & 61 \\
\hline
\end{tabular}

* Buffer was either $1 \%$ DOC, $0.05 \mathrm{M}$ glycine, $0.005 \mathrm{M}$ EDTA, pH 8.8, (DOC), or $0.05 \mathrm{M}$ Tris-Cl, $0.15 \mathrm{M} \mathrm{NaCl}$, pH 7.4 (TS).

dal antibodies were directed appeared to be the most labile. Lot BP2-PA-3, which had not been exposed to DOC in its preparation, was about 10 -fold more active than lot BP2-WZ-2 in this system. The two vaccine lots had approximately equal activity when tested in the SPRIA system, whereas lot 138I-0, which had been shown to be immunogenic in rabbits but poorly immunogenic in man (8), was inactive in both test systems.

Immunogenicity in rabbits. The immunogenicity of the vaccine in rabbits was tested by measuring the antibody response of seven rabbits to each lot. Similar antibody responses were obtained with either intravenous or subcutaneous vaccination and the two lots of vaccine. When all 14 rabbits were considered together,

\section{TABLE III}

Bactericidal Inhibition Assay for the Antigenic Activity of the Group B Polysaccharide Component of Vaccine Lots BP2-WZ-2 and BP2-PA-3

\begin{tabular}{lcr}
\hline \multicolumn{1}{c}{ Inhibitor } & $\begin{array}{c}K_{\mathbf{d}} \text { of poly- } \\
\text { saccharide* }^{*}\end{array}$ & MIC $_{\mathbf{s 0}}$ \\
\hline & & $\mu g / m l$ \\
Lot BP2-WZ-2 & 0.34 & $8 ; 12$ \\
Lot BP2-PA-3 & 0.34 & $9 ; 13$ \\
Lot 3XCA & 0.36 & $25 ; 13$ \\
Lot BP2-WZ-1§ & 0.59 & $100 ; 60$ \\
E. coli Kl capsular polysaccharide & 0.37 & $50 ; 75$ \\
Small group B capsular polysaccharide & 0.63 & $>500$ \\
Strain 138I(C:P2:L3) OMC & & $>1,000$ \\
\hline
\end{tabular}

The killing of strain $99 \mathrm{M}(\mathrm{B})$ by pooled normal human serum was inhibited by serial twofold dilutions of the indicated antigens. The $\mathrm{MIC}_{50}$ was determined graphically. MIC $\mathrm{M}_{50}$ values from two experiments are given.

* Determined on Sepharose CL-4B in the presence of $1 \%$ DOC.

† Described by Wyle et al. (5).

$\S$ This lot was similar in composition to lot BP2-WZ-2 but broke down during its preparation.

" Degraded by exposure to $\mathrm{pH} 5.0$ at $40^{\circ} \mathrm{C}$ for $2 \mathrm{~h}$. 
TABLE IV

Inhibitory Activity of the Protein Antigens in Meningococcal Group B Vaccines

\begin{tabular}{lcc}
\hline \multirow{2}{*}{$\begin{array}{c}\text { Vaccine lot or } \\
\text { antigen }\end{array}$} & \multicolumn{2}{c}{ MIC $_{\text {so }}$ in indicated test system } \\
\cline { 2 - 3 } & Bactericidal* $^{*}$ & SPRIAt \\
\hline 99M OMC & $3 \S$ & $\mu g / m l$ \\
Lot BP2-WZ-2 & 250 & 0.3 \\
Lot BP2-PA-3 & 30 & 5 \\
Lot 138I-0 & $>1,000$ & 3.4 \\
\hline
\end{tabular}

SE is estimated to be plus or minus one twofold dilution.

${ }^{*}$ Killing of strain $99 \mathrm{M}(\mathrm{B}: \mathrm{P2}, 3,6: \mathrm{L} 3,7)$ by human, naturally acquired bactericidal antibodies having serotype P2-associated specificity.

$\$$ Binding of rabbit antibodies raised against viable type P2 meningococci to homologous OMC. This is the SPRIA type P2 serotyping reaction (20).

the geometric mean reciprocal titer of bactericidal antibodies to the vaccine strain $(99 \mathrm{M})$ rose from 4.3 before vaccination to $17.710 \mathrm{~d}$ after the first dose, and to 655 $7 \mathrm{~d}$ after the second dose. It is probable that most of the bactericidal antibodies were directed against the serotype protein antigens because there was a comparable rise in the geometric mean reciprocal titers of bactericidal antibody to a group $\mathrm{C}$ strain of the same protein serotype. (From 1.7 before vaccination to 804 at 5 wk.) Levels of antiprotein antibody as measured by SPRIA with 99M OMC as antigen increased from 1.5 $\mu \mathrm{g} / \mathrm{ml}$ before vaccination to $6.6 \mu \mathrm{g} / \mathrm{ml}$ at $10 \mathrm{~d}$ and to $361 \mu \mathrm{g} / \mathrm{ml}$ at $5 \mathrm{wk}$. When purified LPS was used as antigen in the same assay, the geometric mean antibody level was $0.2 \mu \mathrm{g} / \mathrm{ml}$ before vaccination and $2.2 \mu \mathrm{g} / \mathrm{ml}$ at $5 \mathrm{wk}$. In addition, a mean eightfold increase in antibody titer to the group $B$ polysaccharide was detected in passive HA assays.

The serotype specificity of the SPRIA-detected antiOMC antibodies was investigated as described in Methods. The percentage of antibody specific for the type 2 protein was estimated by this procedure to be $52 \%$ for rabbits immunized with lot BP2-PA-3 and $77 \%$ for those immunized with lot BP2-WZ-2.

Safety and toxicity in animals. The vaccines were tested for safety and toxicity in mice at a level of 115 $\mu \mathrm{g}$ (BP2-WZ-2) or $150 \mu \mathrm{g}$ (BP2-PA-3) dry wt, and for safety in guinea pigs at a 10-fold higher dose. All animals survived, appeared healthy, and showed a weight gain at the end of the 3-and(or) 7-d observation period. In standard rabbit pyrogenicity tests, lot BP2-WZ-2 was found to be nonpyrogenic at a dose of $1 \mu \mathrm{g}$ (dry weight) per kilogram rabbit weight, but a mean temperature rise of $0.75^{\circ} \mathrm{C}$ was observed at a level of 2 $\mu \mathrm{g} / \mathrm{kg}$. Lot BP2-PA-3 was nonpyrogenic at $0.37 \mu \mathrm{g} / \mathrm{kg}$ but produced a mean temperature rise of $1^{\circ} \mathrm{C}$ at $0.5 \mu \mathrm{g} / \mathrm{kg}$.
Preliminary safety and immunogenicity tests in volunteers. Each vaccine lot was tested for safety and immunogenicity in four volunteers as described in Methods. No immediate reactions to the skin tests were observed. After 2-4 h, however, mild local reactions to the skin tests and the vaccinations developed in all volunteers. These reactions were maximum at $24 \mathrm{~h}$, and had disappeared by $72 \mathrm{~h}$. They consisted of erythema frequently accompanied by slight induration and tenderness. After the first injection, the mean diameter of reactions at the skin test site at $24 \mathrm{~h}$ was $2.8 \mathrm{~cm}$ for lot BP2-WZ-2 and $3.5 \mathrm{~cm}$ for lot BP2-PA-3. The mean diameter of the reactions at the vaccination site was $4.8 \mathrm{~cm}$ for lot BP2-WZ-2 and 7.5 for lot BP2-PA-3. Detectable induration was present in all cases. After the second injection at $5 \mathrm{wk}$ the reactions at the skin test site at $24 \mathrm{~h}$ had a mean diameter of $3 \mathrm{~cm}$ for lot BP2WZ-2 and $2.8 \mathrm{~cm}$ for lot BP2-PA-3, but only four of eight had detectable induration. The mean diameter of the reactions at the vaccination site was $3.8 \mathrm{~cm}$ for lot BP2-WZ-2 and $7.0 \mathrm{~cm}$ for lot BP2-PA-3, and only three of eight had detectable induration. No systemic reactions were observed.

All throat cultures were negative for $N$. meningitidis throughout the study. Stool samples from two volunteers (Nos. 6 and 7), however, were consistently found to contain $E$. coli $\mathrm{Kl}$ organisms.

The bactericidal antibody response of the volunteers to the first dose of vaccine was determined by testing the pre- and 2-wk postvaccination sera against several different meningococcal strains (Table V). Six of the eight volunteers developed fourfold or greater increases in bactericidal antibody to the vaccine strain (99M). The two who did not respond had high preexisting titers (1:128 and 1:256). The mean rise to lot BP2-WZ-2 was 32-fold and to lot BP2-PA-3 was about 8 -fold. Bactericidal antibody specific for the $\mathrm{B}$ polysaccharide component of the vaccine was determined by testing the capacity of the sera to kill three different group B strains which lacked the serotype P2 antigen (Table $\mathrm{V}$ ). The titers against these strains were nearly as high as against the vaccine strain, suggesting that much of the bactericidal antibody was directed against the group B polysaccharide. This was confirmed by absorption of the sera with purified $E$. coli $\mathrm{K} 1$ capsular polysaccharide. This absorption removed all bactericidal activity against these nontype P2 strains in both pre- and postvaccination sera.

Bactericidal antibodies against the protein part of the vaccine were assayed by testing the sera against the group C type P2 strain 138I after absorbing with the group $C$ type $P 3,4$ strain $118 \mathrm{~V}$, and also testing the sera against the vaccine strain after absorbing with the group B type P14 strain M981. The resultant titers in the two assays were similar except for volunteer 2 who had antibodies remaining against the vaccine strain but not against 138I (Table V). Seven of the 
TABLE V

Bactericidal Antibody Response of Individual Volunteers to the Initial Dose

of Meningococcal Group B Vaccine

\begin{tabular}{|c|c|c|c|c|c|c|c|c|c|}
\hline \multirow[b]{3}{*}{ Vaccine lot } & \multirow[b]{3}{*}{ Volunteer } & \multicolumn{8}{|c|}{ Reciprocal bactericidal titer vs. indicated test strain } \\
\hline & & \multicolumn{2}{|c|}{$99 \mathrm{M}$} & \multicolumn{2}{|c|}{$\begin{array}{c}\text { Group B* } \\
\text { nontype P2 }\end{array}$} & \multicolumn{2}{|c|}{$\begin{array}{l}\text { Group C } \\
\text { type P2 }\end{array}$} & \multicolumn{2}{|c|}{$99 \mathrm{M} \S$} \\
\hline & & Pre & $2 w k$ & Pre & $2 w k$ & Pre & $2 \mathrm{wk}$ & Pre & $2 w k$ \\
\hline \multirow[t]{4}{*}{ BP2-WZ-2 } & 1 & 0 & 512 & 1.6 & 256 & 0 & 64 & 0 & 64 \\
\hline & 2 & 64 & 2,084 & 20 & 1,024 & 0 & 0 & 0 & 64 \\
\hline & 3 & 256 & 256 & 102 & 128 & 0 & 0 & 0 & $\mathbf{0}$ \\
\hline & 4 & 64 & 4,096 & 25 & 1,024 & 0 & 8 & 0 & 16 \\
\hline \multirow[t]{4}{*}{ BP2-PA-3 } & 5 & 8 & 128 & 0 & 32 & 0 & 256 & 0 & 128 \\
\hline & 6 & 32 & 256 & 25 & 256 & 0 & 2 & 0 & 2 \\
\hline & 7 & 64 & 256 & 32 & 128 & 0 & 256 & 0 & 256 \\
\hline & 8 & 128 & 256 & 51 & 79 & 0 & 4 & 0 & 2 \\
\hline
\end{tabular}

* Geometric mean of titers against strains 6155(B:P9:L3,7), M136(B:P4,7:L4), and M1080(B:P11:

$\mathrm{L} 3,4,7,8)$. Individual titers were within one twofold dilution of the mean.

† Sera absorbed with 118V(C:P3,4:L2,4) were tested against 138I(C:P2:L3).

\$Sera absorbed with M981(B:P14:L5).

eight volunteers had a detectable rise in titer against one of the two strains. Further absorption of these sera with 99M LPS failed to remove this antibody. This strongly suggested that seven of the volunteers had developed type-specific bactericidal antibody against the protein antigens.

The persistence of the bactericidal antibodies induced by the vaccine and the effect of a second dose of vaccine given at $5 \mathrm{wk}$ is summarized in Table VI. In contrast to the strong antibody response of rabbits to a second dose of vaccine, only a slight booster effect was observed in the volunteers. The geometric mean group B antibody titers (vs. strain 6155), which had decreased from the 2-wk level, were partially restored but did not reach the original 2-wk level. At 14 wk the titers had again fallen off but remained approximately sixfold above the prevaccination level. Bactericidal antibodies to the protein antigens (vs. strain 138I) also decreased and at $14 \mathrm{wk}$ had completely disappeared in those who received lot BP2-PA-3.

Antibodies to the outer membrane proteins were also assayed by SPRIA by using OMC from strain 99M as antigen (Table VII). Because the OMC contains LPS antigens as well as outer membrane proteins, the sera were also tested against purified 99M LPS as a control. The difference between the amount of antibody binding to the OMC and that binding to the LPS was assumed to represent antibody binding to outer membrane proteins. In the postvaccination sera, over $95 \%$ of the antibody that bound to the OMC appeared to be directed against the proteins. All eight volunteers responded to the first dose of vaccine with increased levels of antibody to the outer membrane proteins. The range of the rises was 2- to 30 -fold, and the mean rise for both vaccine lots was about 8-fold. Little if any increase resulted from the second dose. The antibody levels dropped by $\cong 50 \%$ through the first $14 \mathrm{wk}$. A slight increase in antibodies to LPS was seen with lot BP2-PA-3.

The specificity of the antiprotein antibodies measured by SPRIA was determined as described in Meth-

TABLE VI

Duration of Human Bactericidal Antibody Response and Effect of Booster Dose*

\begin{tabular}{lcrccc}
\hline & & & \multicolumn{3}{c}{ Test strain } \\
\cline { 3 - 6 } Vaccine lot & $\begin{array}{c}\text { Volun- } \\
\text { teers }\end{array}$ & Serum & $\begin{array}{c}6155 \\
\text { (B:P9:L3,7) }\end{array}$ & $\begin{array}{c}\text { 138It } \\
\text { (C:P2:L3) }\end{array}$ \\
\hline & $n$ & $w k$ & & & \\
BP2-WZ-2 & 4 & 0 & $23(0-64) \S$ & \multicolumn{1}{l}{0} \\
& & 2 & $512(128-1,024)$ & $2.8(0-64)$ \\
& & 5 & $181(64-512)$ & $3.5(0-64)$ \\
& & 7 & $256(64-512)$ & $4.8(0-64)$ \\
& & 10 & $128(16-512)$ & $3.5(0-32)$ \\
BP2-PA-3 & 4 & 14 & $128(32-256)$ & $2.4(0-32)$ \\
& & 0 & $10(0-32)$ & 0 & \\
& & 2 & $108(32-256)$ & 27 & $(2-256)$ \\
& & 5 & $54(8-128)$ & 23 & $(2-256)$ \\
& & 7 & $91(64-256)$ & 13 & $(2-128)$ \\
& & 10 & $54(32-128)$ & 8 & $(0-32)$ \\
& & 14 & $64(32-256)$ & 0 & \\
\hline
\end{tabular}

Zero indicates $<2$.

* Second dose was given at 5 wk.

\$ Sera were absorbed with $118 \mathrm{~V}(\mathrm{C}: \mathrm{P3}, 4: \mathrm{L} 2,4)$.

$\S$ Geometric mean reciprocal titer with range given in parentheses. 
TABLE VII

Antibody Response to the Protein Antigens in Meningococcal Group B Vaccines as Determined by SPRIA

\begin{tabular}{|c|c|c|c|c|c|}
\hline \multirow[b]{2}{*}{ Vaccine lot } & \multirow{2}{*}{$\begin{array}{l}\text { Volun- } \\
\text { teers }\end{array}$} & \multirow[b]{2}{*}{ Serum } & \multicolumn{3}{|c|}{$\begin{array}{l}\text { Mean antibody concentration } \\
\text { vs. indicated antigen* }\end{array}$} \\
\hline & & & & OMC & LPS \\
\hline & $n$ & $w k$ & & & \\
\hline \multirow[t]{6}{*}{ BP2-WZ-2 } & 4 & 0 & & $(1.7-14)$ & $0.71(0.52-0.92)$ \\
\hline & & 2 & 54 & $(17-165)$ & $0.96(0.52-3.4)$ \\
\hline & & 5 & 40 & $(18-57)$ & $0.78(0.50-2.2)$ \\
\hline & & 7 & 40 & $(18-77)$ & $0.8(0.47-1.8)$ \\
\hline & & 10 & 35 & $(15-60)$ & $0.76(0.37-1.9$ \\
\hline & & 14 & 37 & $(16-52)$ & $0.98(0.65-1.2)$ \\
\hline \multirow[t]{6}{*}{ BP2-PA-3 } & 4 & 0 & & $(1.5-11)$ & $1.0(0.5-3.5)$ \\
\hline & & 2 & 46 & $(23-93)$ & $1.9(1.3-3.0)$ \\
\hline & & 5 & 33 & $(16-75)$ & $1.8(1.2-3.5)$ \\
\hline & & 7 & 35 & $(16-79)$ & $1.5(0.5-3.6)$ \\
\hline & & 10 & 31 & $(12-66)$ & $1.4(0.5-3.1)$ \\
\hline & & 14 & 22 & $(11-39)$ & $1.0(0.4-2.2)$ \\
\hline
\end{tabular}

* Antigens were derived from the vaccine strain. Data are expressed as geometric mean micrograms antibody per milliliter, with range given in parentheses.

ods. A mean of $63 \%$ of the antiprotein antibodies induced by lot BP2-WZ-2 and $47 \%$ of those induced by lot BP2-PA-3 were specific for the type 2 protein (Table VIII).

Increases in antibody to the group B polysaccharide were confirmed by passive HA assays. Lot BP2-WZ-2 induced a mean eightfold rise in $\mathrm{HA}$ antibody to the $B$ polysaccharide which decreased to fourfold after 14 wk (Table IX). Similarly, lot BP2-PA-3 induced a mean fivefold rise which decreased to threefold after

TABLE VIII

Specificity of Postvaccination Antibodies to Outer Membrane Proteins as Determined by Inhibition of SPRIA

\begin{tabular}{|c|c|c|c|c|c|}
\hline \multirow[b]{2}{*}{ Vaccine lot } & \multirow[b]{2}{*}{$\begin{array}{l}\text { Volun- } \\
\text { teers }\end{array}$} & \multicolumn{3}{|c|}{$\begin{array}{l}\text { Mean percentage of inhibition of } \\
\text { 2-wk sera by indicated OMC* }\end{array}$} & \multirow{2}{*}{$\begin{array}{c}\text { Per- } \\
\text { centage of } \\
\text { type P2 } \\
\text { antibodies }\end{array}$} \\
\hline & & $\begin{array}{l}\text { Homolo- } \\
\text { gous }\end{array}$ & Type P2 & $\begin{array}{l}\text { Nontype } \\
\text { P2 }\end{array}$ & \\
\hline & $n$ & & & & \\
\hline BP2-WZ-2 & 4 & $\begin{array}{c}87.3 \\
(77-92) \S\end{array}$ & $\begin{array}{c}71.3 \\
(47-80)\end{array}$ & $\begin{array}{c}16 \\
(8-26)\end{array}$ & $\begin{array}{c}63 \\
(43-80)\end{array}$ \\
\hline BP2-PA-3 & 4 & $\begin{array}{c}90.8 \\
(84-95)\end{array}$ & $\begin{array}{c}72.3 \\
(51-83)\end{array}$ & $\begin{array}{c}29 \\
(6-52)\end{array}$ & $\begin{array}{c}47 \\
(15-75)\end{array}$ \\
\hline
\end{tabular}

*All inhibitors were tested at a concentration of $100 \mu \mathrm{g}$ protein $/ \mathrm{ml}$.

$\ddagger$ Mean inhibition of four sera by OMC from three different strains.

$\S$ The values in parentheses give the range for the four volunteers.
$14 \mathrm{wk}$. Six of the eight volunteers had a 4-fold or greater rise, and one volunteer (No. 4) had a 64-fold rise at 2 wk.

The immunoglobulin class of the anti-group B polysaccharide antibodies was determined by fractionation of a pool of the 10-wk postvaccination sera from volunteers 2 and 4 . The IgM, IgG, and IgA fractions, which exhibited cross-contamination of $<1 \%$ based on assays with low level radial immunodiffusion plates, were tested for antibody to the group B polysaccharide by bactericidal and $\mathrm{HA}$ assays (Table $\mathrm{X}$ ). Bactericidal and $\mathrm{HA}$ antibodies appeared to be mostly of the IgM class. Group B-specific IgG antibodies were present at much lower titer and group Bspecific IgA antibodies were not detected, although IgA antibodies were detected by HA (equivalent titer 1:32) after similar fractionation of 5-wk sera from the same individuals. Preliminary tests with a sensitive radioactive antigen binding assay have also failed to demonstrate a good IgG response to the group B polysaccharide.

That the antibody response to the protein component of the vaccine involved antibodies of all three major immunoglobulin classes was demonstrated by the SPRIA using heavy chain-specific second antibody (Table XI). The pre- and postimmunization sera from two volunteers who received lot BP2-WZ-2 were assayed. In both cases IgG antibodies showed the largest increase, and the IgA antibodies appeared to be the least persistent.

\section{DISCUSSION}

Immunization of a small number of volunteers with a noncovalent complex of meningococcal group B polysaccharide and type 2 outer membrane proteins has demonstrated that both components of the complex are immunogenic in man when presented in this form. The complex described here, which involved noncovalent hydrophobic binding between two surface antigens, may be very similar to the natural association of these antigens on the surface of the viable organism. The group B polysaccharide component of the present vaccines was only slightly larger and more antigenic than a purified group B polysaccharide vaccine (lot 3XCA) found by Wyle et al. (5) to lack immunogenicity in man. This suggests that the immunogenicity of the group $B$ polysaccharide in the present vaccine is largely a result of its binding to the outer membrane protein. Increased immunogenicity of bacterial polysaccharides in animals as a result of being bound to protein has been reported $(17,18)$ and may result from conversion of the polysaccharide from a $\mathrm{T}$-cell-independent to a $T$-cell-dependent antigen. Alternatively, the protein may hold the polysaccharide in a conformation that is antigenically more active. 
Although the evaluation and standardization of this type of polysaccharide-protein vaccine is more difficult than if the vaccine were a single purified antigen, the advantages of such a complex would appear to more than compensate for the increased complexity. In addition to increasing the immunogenicity of the group B polysaccharide, the binding of the polysaccharide to the protein resulted in solubilization of the protein component and possibly in an increase in its immunogenicity as well. It seems probable that the presence of both group-specific and type-specific antibodies would provide greater protection than either specificity alone. Synergism in protection by group B-specific and serotype 2-specific antibodies has been demonstrated in a chick embryo model (19). Now that the immunogenicity of this type of protein-polysaccharide complex has been demonstrated in man, base-line immunogenicity and safety data can be obtained which will provide a reference point for future studies directed toward standardization of the vaccine and optimizing its composition with respect to the protein species present.

The group B-specific antibodies might, in theory, be expected to protect against all group B strains, but there is some evidence that suggests that the group B-specific antibodies may not be of sufficiently high quality to provide uniform, long-lasting protection against all group B strains (7). In this case, serotype P2-specific antibodies may provide important backup protection against at least type $\mathrm{P} 2$ strains which have figured prominently in recent group B and group C epidemics $(2,12,13)$. Type P2-specific antibodies

\section{TABLE IX}

Human HA Antibody Response to the Group B Polysaccharide Complement of Meningococcal Vaccine Lots BP2-WZ-2 and BP2-PA-3

\begin{tabular}{lcrrrrrr}
\hline & & \multicolumn{6}{c}{$\begin{array}{c}\text { Reciprocal HA titer of serum at } \\
\text { indicated week }\end{array}$} \\
\cline { 3 - 8 } Vaccine lot & $\begin{array}{c}\text { Volun- } \\
\text { teer }\end{array}$ & 0 & 2 & 5 & 7 & 10 & 14 \\
\hline BP2-WZ-2 & 1 & 4 & 32 & 32 & 64 & 32 & 32 \\
& 2 & 8 & 64 & 32 & 32 & 32 & 32 \\
& 3 & 16 & 16 & 16 & 16 & 16 & 16 \\
& 4 & 4 & 256 & 64 & 64 & 32 & 32 \\
Geometric & & & & & & & \\
mean & & 6.7 & 54 & 32 & 38 & 27 & 27 \\
BP2-PA-3 & 5 & 8 & 32 & 8 & 16 & 16 & 16 \\
& 6 & 4 & 64 & 64 & 64 & 32 & 32 \\
& 7 & 8 & 32 & 32 & 32 & 32 & 32 \\
Geometric & 8 & 8 & 16 & 16 & 16 & 16 & 16 \\
mean & & & & & & & \\
\hline
\end{tabular}

Vaccine was administered at 0 and 5 wk.
TABLE X

Immunoglobulin Class of Antibodies to the Group B Polysaccharide in 10-Wk Postvaccination Sera

\begin{tabular}{lccc}
\hline $\begin{array}{c}\text { Serum } \\
\text { fraction }\end{array}$ & $\begin{array}{c}\text { Equivalent } \\
\text { dilution }\end{array}$ & $\begin{array}{c}\text { Bactericidal } \\
\text { activity vs. } \\
\text { strain } 99 M^{*}\end{array}$ & $\begin{array}{c}\text { HA titer vs. } \\
\text { group B } \\
\text { polysaccharide* }\end{array}$ \\
\hline $\begin{array}{c}\text { Unfractionated } \\
\text { serum }\end{array}$ & & & \\
IgM pool & $1: 8$ & $1: 256$ & $1: 64$ \\
IgG pool & $1: 4$ & $1: 8$ & $1: 32$ \\
IgA pool & $1: 8$ & $<1: 8$ & $1: 8$ \\
\hline
\end{tabular}

10-wk sera from volunteers 2 and 4 were pooled and fractionated (33) to separate the immunoglobulin classes.

* Titers are expressed as the reciprocal equivalent serum dilution.

alone, however, would not protect against many of the group B strains currently causing endemic disease in this country. ${ }^{4}$

The determinant on group B polysaccharide against which human bactericidal antibodies are directed is of considerable interest. Inasmuch as low molecular weight group B polysaccharide is not active as a hapten in inhibiting human bactericidal antibodies (Table III), the active determinant must not simply be the main polysaccharide chain which has the same $\alpha, 2 \rightarrow 8$ linkage as the two sialic acid residues on the $G_{T 1}$ and $G_{D 1 b}$

${ }^{4}$ Broud, D. C., J. M. Griffiss, and C. J. Baker. 1978. Abstracts of the Annual Meeting of the American Society for Microbiology, Las Vegas, Nev. B25. 17.

TABLE XI

SPRIA Quantitation of IgG, IgA, and IgM Antibodies to OMC in Sera of Two Volunteers Immunized with Meningococcal Group B Vaccine Lot BP2-WZ-2

\begin{tabular}{ccccc}
\hline & & \multicolumn{3}{c}{$\begin{array}{c}\text { Anti-99M OMC antibody of } \\
\text { indicated class }\end{array}$} \\
\cline { 3 - 5 } Volunteer & Serum & IgG & IgA & IgM \\
\hline \multirow{3}{*}{2} & $w k$ & $\mu g / m l$ & $\mu g / m l$ & $\mu g / m l$ \\
& 0 & 6.7 & 3.3 & 7.4 \\
& 2 & 112 & 26 & 18 \\
& 5 & 73 & 9.1 & 16 \\
& 7 & 68 & 10 & 16 \\
4 & 10 & 53 & 6.8 & 15 \\
& 14 & 40 & 4.6 & 13 \\
& 0 & 3.2 & 1.1 & 3.6 \\
& 2 & 48 & 10 & 16 \\
& 5 & 53 & 5.1 & 13 \\
& 7 & 51 & 5.0 & 13 \\
& 10 & 48 & 3.9 & 13 \\
& 14 & 37 & 3.1 & 10 \\
\hline
\end{tabular}


gangliosides (39). This conclusion is supported by our unpublished observation that several human sera with group B-specific bactericidal antibody titers in excess of 1:1000 failed to effect complement-mediated lysis of $\mathrm{G}_{\mathrm{T}_{1}}$-sensitized liposomes. ${ }^{5}$

Because animal models have thus far been relatively useless for predicting human antibody responses to meningococcal antigens, several in vitro assays were developed to monitor the antigenic activity and specificity of the vaccine components. These assays involved quantitation of the capacity of an antigen preparation to inhibit the reaction of human antibodies or rabbit antibodies induced by the native form of the antigen with the native antigen. In the case of the protein, the SPRIA test system (Table IV) was able to clearly distinguish between an earlier vaccine lot that was exposed to high $\mathrm{pH}$ during its preparation and was poorly immunogenic in man and the present vaccines in which the protein component produced a much stronger antibody response in man. Such assays may, therefore, be useful for monitoring the antigenic activity of the protein antigens in the vaccine.

The limited data obtained in this initial study suggest that the vaccine is safe. Adverse side effects were limited to local reactions which, although stronger than those normally seen with purified meningococcal polysaccharide vaccines $(5,40,41)$, were relatively mild and disappeared in 2 or $3 \mathrm{~d}$. Whether the reactogenicity is directly related to the level of contaminants, such as endotoxin, or is an intrinsic property of the proteinpolysaccharide complex is presently under investigation.

Vaccine lots BP2-WZ-2 and BP2-PA-3 differed mainly in the method of their preparation and in the relative proportions of the separate components present. The principal reason for testing lot BP2-PA-3, which had a higher level of contaminating LPS, was that the protein in that lot appeared to have greater antigenic activity than the protein in lot BP2-WZ-2, presumably because it had not been exposed to DOC. We had thus anticipated that lot BP2-PA-3 might produce an antibody response to the protein, whereas lot BP2-WZ-2 might not. Although only a few volunteers were vaccinated in this initial phase of testing, it was clear that the two lots were roughly equivalent in their capacity to induce an antibody response to the proteins as determined by SPRIA. Lot BP2-PA-3, however, appeared to produce a higher mean type-specific bactericidal antibody response, but the numbers are too small to be certain.

To determine whether the level and quality of the antibody response to the vaccines is sufficient to provide effective, long-lasting protection will require efficacy trials in a suitable population experiencing group $B$ meningococcal disease. An evaluation of the nature

${ }^{5}$ Zollinger, W. D., and C. Alving. Unpublished observations. of the antibody response obtained in these few initial volunteers, however, has revealed some significant differences between the human antibody response to the group B polysaccharide and that to the group $A$ and group $\mathrm{C}$ polysaccharides. For example, Gotschlich et al. (14) found that although all three classes of antibodies were induced by the meningococcal group $\mathrm{A}$ and $\mathrm{C}$ vaccines, the bactericidal antibodies were predominantly of the IgG class. This is in sharp contrast to our finding that the bactericidal antibodies induced by the present group B vaccine were nearly all of the IgM class. The IgM character of these antibodies may explain the observed decline of the antibody titers over a 3-mo period.

Although two of the volunteers had little or no antibody response to the group B polysaccharide, they were the two with the highest prevaccination titers of bactericidal antibody. Those volunteers with the lowest prevaccination titers, and therefore most in need of protection, were among the strongest responders. As protection has been correlated with the presence of serum bactericidal antibodies $(15,16)$, it is reasonable to expect that the bactericidal antibodies induced by these vaccines will be protective, and although serum bactericidal antibodies decreased considerably over a period of $14 \mathrm{wk}$, mean titers remained above the prevaccination levels. In addition, because military recruits are at greatest risk during their initial 7 wk of basic training, even shorter protection would be of significant value in this setting. Noncovalent complexes of group B polysaccharide and outer membrane protein thus appear to have considerable potential as a vaccine against group B meningococcal disease and warrant further development and testing in larger numbers of volunteers.

\section{ACKNOWLEDGMENTS}

The authors wish to express appreciation to Hans Hansel and Richard Pittman for excellent technical assistance, and to Jean Guidas and Lydia P. Scarlis for their help in the preparation of the manuscript.

\section{REFERENCES}

1. The Meningococcal Disease Surveillance Group. 1976. Analysis of endemic meningococcal disease by serogroup and evaluation of chemophrophylaxis. J. Infect. Dis. 134: 201-204.

2. Bovre, K., E. Holten, H. Vik-Mo, A. Brondbo, D. Bratlid, P. Bjark, and P. J. Moe. 1977. Neisseria meningitidis infections in northern Norway: an epidemic in 1974-75 due mainly to group B organisms. J. Infect. Dis. 135: 669-672.

3. Jones, D. M., and B. M. Tobin. 1976. Serotypes of group B meningococci. J. Clin. Pathol. (Lond.). 29: 746-748.

4. Gotschlich, E. C., I. Goldschneider, and M. S. Artenstein. 1969. Human immunity to the meningococcus. IV. Immunogenicity of group $\mathbf{A}$ and group $\mathbf{C}$ meningococcal polysaccharides in human volunteers. J. Exp. Med. 129: 1367-1384. 
5. Wyle, F. A., M. S. Artenstein, B. L. Brandt, E. C. Tramont, D. L. Kasper, P. L. Altieri, S. L. Berman, and J. P. Lowenthal. 1972. Immunologic response of man to group B meningococcal polysaccharide vaccines. J. Infect. Dis. 126: $514-522$.

6. Zollinger, W. D., C. L. Pennington, and M. S. Artenstein. 1974. Human antibody response to three meningococcal outer membrane antigens: comparison by specific hemagglutination assays. Infect. Immun. 10: 975-984.

7. Kasper, D. L., J. L. Winkelhake, B. L. Brandt, and M. S. Artenstein. 1973. Antigenic specificity of bactericidal antibodies in antisera to Neisseria meningitidis. J. Infect. Dis. 127: 378-387.

8. Zollinger, W. D., R. E. Mandrell, P. Altieri, S. Berman, J. Lowenthal, and M. S. Artenstein. 1978. Safety and immunogenicity of a meningococcal type 2 protein vaccine in animals and human volunteers. J. Infect. Dis. 137: 728-739.

9. Hill, J. C., and E. Weiss. 1974. Protein fraction with immunogenic potential and low toxicity isolated from the cell wall of Neisseria meningitidis group B. Infect. Immun. 10: 605-615.

10. Jennings, H. J., A. Martin, C. P. Kenney, and B. B. Diena. 1972. Cross-protective antigens of Neisseria meningitidis obtained from Slaterus group Y. Infect. Immun. 5: 547-551.

11. Frasch, C. E., and J. B. Robbins. 1978. Protection against group B meningococcal disease. III. Immunogenicity of serotype 2 vaccines and specificity of protection in a guinea pig model. J. Exp. Med. 147: 629-644.

12. Frasch, C. E., and S. S. Chapman. 1973. Classification of Neisseria meningitidis group B into distinct serotypes. III. Application of a new bactericidal-inhibition technique to distribution of serotypes among cases and carriers. J. Infect. Dis. 127: 149-154.

13. Griffiss, J. M., D. D. Broud, C. A. Silver, and M. S. Artenstein. 1977. Immunoepidemiology of meningococcal disease in military recruits. I. A model for serogroup independency of epidemic potential as determined by serotyping. J. Infect. Dis. 136: 176-186.

14. Gotschlich, E. C., T. Y. Liu, and M. S. Artenstein. 1969. Human immunity to the meningococcus. III. Preparation and immunochemical properties of the group A, group B, and group $\mathrm{C}$ meningococcal polysaccharide.J. Exp. Med. 129: $1349-1365$.

15. Goldschneider, I., E. C. Gotschlich, and M. S. Artenstein. 1969. Human immunity to the meningococcus. I. The role of humoral antibodies. J. Exp. Med. 129: 1307-1326.

16. Lim, D., A. Gewurz, T. F. Lint, M. Ghase, B. Sepheri, and H. Gewurz. 1976. Absence of the sixth component of complement in a patient with repeated episodes of meningococcal meningitis. J. Pediatr. 89: 42-47.

17. Anderson, P., and D. H. Smith. 1977. Immunogenicity in weanling rabbits of a polyribophosphate complex from Haemophilus influenza type b. J. Infec. Dis. 136(Suppl.): S63-S70.

18. Cheng, W. C., E. Webb, N. Vedros, and N. James. 1975. Fractionation and characterization of surface antigens from group A Neisseria meningitidis. J. Immunol. 114: 1497-1505.

19. Frasch, C. E., L. Parkes, R. M. McNelis, and E. C. Gotschlich. 1976. Protection against group B meningococcal disease. I. Comparison of group-specific and type-specific protection in the chick embryo model. J. Exp. Med. 144: 319-329.

20. Zollinger, W. D., and R. E. Mandrell. 1977. Outer membrane protein and lipopolysaccharide serotyping of Neis- seria meningitidis by inhibition of a solid-phase radioimmunoassay. Infect. Immun. 18: 424-433.

21. Frasch, C. E., and S. S. Chapman. 1972. Classification of Neisseria meningitidis group B into distinct serotypes. I. Serological typing by a microbactericidal method. Infect. Immun. 5: 98-102.

22. Gold, R., and F. A. Wyle. 1970. New classification of Neisseria meningitidis by means of bactericidal reactions. Infect. Immun. 1: 479-484.

23. Berman, S., P. L. Altieri, A. Groffinger, and J. P. Lowenthal. 1970. Pilot-scale production of group $\mathrm{A}$ and group $\mathrm{C}$ meningococcal polysaccharide immunogens. Infect. Immun. 2: 640-643.

24. Watson, R. G., and H. W. Sherp. 1958. The specific hapten of group C (group IIa) meningococcus. I. Preparation and immunological behavior. J. Immunol. 81: 331-336.

25. Wong, K. H., O. Barrera, A. Sutton, J. May, D. H. Hochstein, J. D. Robbins, J: B. Robbins, P. D. Parkman, and E. B. Seligman, Jr. 1977. Standardization and control of meningococcal vaccines, group $\mathrm{A}$ and group $\mathrm{C}$ polysaccharides. J. Biol. Stand. 5: 197-215.

26. Brunk, C. F., and V. Leick. 1969. Rapid equilibrium isopycnic CsCl gradients. Biochim. Biophys. Acta. 179: 136- 144 .

27. Laemmli, U. K. 1970. Cleavage of structural proteins during the assembly of the head of bacteriophage T4. Nature (Lond.). 227: 680-685.

28. Weber, K., and M. Osborne. 1969. The reliability of molecular weight determination by dodecyl sulfate-polyacrylamide gel electrophoresis. J. Biol. Chem. 244: 4406-4412.

29. Kasper, D. L., and F. A. Wyle. 1972. Bactericidal antibody assay using ${ }^{14} \mathrm{C}$-labeled Neisseria meningitidis. Proc. Soc. Exp. Biol. Med. 139: 1175-1180.

30. Goldschneider, I., E. C. Gotschlich, and M. S. Artenstein. 1969. Human immunity to the meningococcus. II. Development of natural immunity.J. Exp. Med. 129: 1327-1348.

31. Zollinger, W. D., J. M. Dalrymple, and M. S. Artenstein. 1976. Analysis of parameters affecting the solid phase radioimmunoassay quantitation of antibody to meningococcal antigens. J. Immunol. 117: 1788-1798.

32. Artenstein, M. S., B. L. Brandt, E. C. Tramont, and W. D. Zollinger. 1976. Immune response to Neisseria meningitidis. In Manual of Clinical Immunology. N. R. Rose and H. Friedman, editors. American Society for Microbiology, Washington, D. C. 274.

33. Griffiss, J. M., M. A. Bertram, and D. D. Broud. 1974. Separation and purification of IgM, IgA and IgG from small volumes of human sera by a continuous, in-line chromatographic process (GV-2). J. Chromatogr. 156: 121-130.

34. Artenstein, M. S., J. H. Rust, D. H. Hunter, T. H. Lamson, and E. L. Buescher. 1967. Acute respiratory disease and meningococcal infection in Army recruits. JAMA (J. Am. Med. Assoc.) 201: 1004-1008.

35. Sivonen, A., O-V. Renkonen, and J. B. Robbins. 1977. Use of antiserum agar plates for serogrouping of meningococci. J. Clin. Pathol. 30: 834-837.

36. Frasch, C. E., and E. C. Gotschlich. 1974. An outer membrane protein of Neisseria meningitidis group B responsible for serotype specificity. J. Exp. Med. 140: 87-104.

37. Kasper, D. L., J. L. Winkelhake, W. D. Zollinger, B. L. Brandt, and M. S. Artenstein. 1973. Immunochemical similarities between polysaccharide antigens of Escherichia coli $07: \mathrm{Kl}(\mathrm{L}): \mathrm{MN}$ and group B Neisseria meningitidis. J. Immunol. 110: 262-268.

38. Maloney, P. C., H. Schneider, and B. L. Brandt. 1972. 
Production and degradation of serogroup B Neisseria meningitidis polysaccharide. Infect. Immun. 6: 657661.

39. Bhattacharjee, A. K., H. J. Jennings, C. P. Kenny, A. Martin, and I. C. P. Smith. 1975. Structural determination of the sialic acid polysaccharide antigens of Neisseria meningitidis serogroups $B$ and $C$ with carbon 13 nuclear magnetic resonance. J. Biol. Chem. 250: 1926-1932.

40. Artenstein, M. S., R. Gold, J. G. Zimmerly, F. A. Wyle,
W. C. Branche, Jr., and C. Hawkins. 1970. Cutaneous reactions and antibody response to meningococcal group C polysaccharide vaccines in man. J. Infect. Dis. 121: 372-377.

41. Peltola, H., H. Kayhty, T. Kuronen, N. Hague, S. Sarna, and P. H. Makela. 1978. Meningococcus group A vaccine in children three months to five years of age: adverse reactions and immunogenicity related to endotoxin content and molecular weight of the polysaccharide. $J$. Pediatr. 92: 818-822. 